\title{
Comparison Member and Candidate Countries to the European Union by Means of Main Health Indicators*
}

\author{
Fatma Lorcu \\ Trakya University, Edirne, Turkey \\ Bilge Acar Bolat \\ Istanbul University, Istanbul, Turkey
}

\begin{abstract}
Throughout history, health policies and the institutionalization of health care have taken shape according to political and economic conditions, social structures and value systems of societies, as well as to their needs and changes in health conditions. Today, economic development is addressed from a different approach in which the issue of health plays an important part. With a focus on the health sector's role in development, this new approach has increased the importance of this sector of government and of life, allowing data on health to be included in many countries' development indicators. The aim of this study is to identify the differences between EU former member states, member states, and candidate countries (including Turkey) in terms of health indicators that have become the key indicators of social and economic development. In this study, discriminant analysis will be used in order to analyse the differences between the European Union (EU) countries, and candidate countries in terms of main health indicators. Under-five mortality rate (\%), health expenditure per capita (PPP US\$), total expenditure on health as percent of gross domestic product expenditure (percentage of GDP), immunization coverage among one-year-olds with one dose of measles (\%), prevalence of current tobacco use among adults ( $\geq 15$ years) (\%), per capita recorded alcohol consumption (litres of pure alcohol) among adults, total fertility rate (\%), hospital beds (per 1,000 population), physicians (per 1,000 population) and life expectancy are all included in the analysis as main health indicators of a country's fitness for acceptance into the EU. As a result of the analysis, the discriminant variables that determine the statuses of former member, member, and candidate countries in terms of health indicators are identified "health expenditures per capita" and "life expectancy". Another striking result is that Romania and Bulgaria, which became full member states in 2007, had similar health indicators to Turkey’s in 2004.
\end{abstract}

Keywords: health indicators, discriminant analysis, European Union, Turkey

\section{Introduction}

The European Union agreed on final arrangements to enable Bulgaria and Romania to join in 2007. This raised

\footnotetext{
* An earlier version of this paper was presented at 12th International Symposium on Econometrics Operations Research and Statistics in Denizli/Turkey, May 2011.

Fatma Lorcu, Ph.D., Assistant Professor, Faculty of Economics and Administrative Sciences, Trakya University. Bilge Acar Bolat, Ph.D., Research Assistant, School of Business, Istanbul University.

Correspondence concerning this article should be addressed to Bilge Acar Bolat, School of Business, Istanbul University, Avc1lar, Istanbul, Turkey. E-mail: bacar@istanbul.edu.tr; fatmalorcu@trakya.edu.tr.
} 
the number of members from 25 to 27. Romania and Bulgaria submitted their formal applications for membership of the EU in 1995. Turkey is still an official candidate although Turkey applied for associate membership in the European Economic Community in 1963, and the earliest date that Turkey could enter the EU is 2013.

In contrast to Romania's and Bulgaria's short and painless admission to the Union, Turkey, which in fact is comparable to those countries, still has to live through a long-haul process. On the other hand, "choosing adequate strategies for the future of countries in an increasingly globalise world", Turkey and its variety of sectors have to "find its places among other countries", and in this respect knowledge about the influential general factors is one of the most important aspects of the discussion (Ay, 2007, p. 4).

One of the most important of these sectors is the health sector, which is in fact gaining importance day by day and is an indicator of socio-economic development. One is likely to come across some literature dealing with the significance of health indicators, while making important comparisons between Turkey and other countries. In this context Gauld, Ikegami, Barr, Chiang, Gould, and Kwon (2006) discusses health systems in economically developed Asian countries, while Vehid (2000), Yıldırım (2004), Kisa, Younis, and Kisa (2007) and Pacifico (2004) compare the health systems in a number of EU countries. On the other hand, Bal and Orkcu (2005) analyse the socio-economic indicators of EU members, and those chosen to become members, by using a newly developed categorisation technique which was based on discriminate analysis and data envelopment analysis.

Our study has two goals. The first is to analyse whether health status differences exists between EU former members, current members, and candidates, and if so. The second is to find out if health status has a significant association with becoming an EU member. In order to achieve these goals, member and candidate countries are classified into three groups: former member-current member-future member; when dealing with issues of health, it will be outlined which variables current EU member states differ from those of the future. The analysis will use the 2004 findings for the 28 concerned countries. The reason for the choice of material from 2004 is that Turkey, Romania and Bulgaria at that time were all given the future member state status. In this respect, the analysis will be able to assess and question the validity of the EU's decisions with regards to the grouping of these countries. It is a well-known fact that Bulgaria and Romania became EU members in 2007, with less regulation to comply with, despite the fact that their future member status was granted later than in the case of Turkey. The research will compare the three countries and their individual general health situations in 2004 when all were regarded as future member states, and it will reveal if Turkey's situation was any different.

The data used in this paper is cross sectional data set covering 28 countries, of which 25 are EU member states, two are due to join the EU in 2007 (Bulgaria and Romania) and one is a potential member state (Turkey). The data is from the OECD Health Data 2004 for OECD countries, and from the WHO (European health for all database) for non-OECD countries.

Section two explains our methodology and techniques. Section three summarizes definitions of variables which are used in the analysis by literature. Section four concludes the paper by analyzing results and developing suggestions.

\section{Method}

In order to meet objectives identified above, two methods are applied: Logistic regression and discriminant analysis. However, since normality of independent variables among groups is present and an assumption of 
equality between group variance-covariance matrices is provided, using the discriminant analysis method is considered to be appropriate.

With the help of the discriminant analysis the following can be determined:

- The difference amongst groups within variable sets;

- The identification of variables which determine the differences between groups;

- The contribution of distinctive variables to the function;

- The percent of variance in the dependent variable explained by independent;

- The level of groups' membership prediction accuracy (Hair, Anderson, Tatham, \& Black, 1998, p. 256).

The discriminant function can be written as follows:

$$
D=b_{1} x_{1}+b_{2} x_{2}+\ldots+b_{n} x_{n}+c
$$

the $b$ 's represent the discriminant coefficients, the $x$ 's the discriminating (independent) variables and the $c$ 's the constants. Regression equations are similar to the equation, but here the $b$ coefficients specify the coefficients which maximize the distance between the means of the dependent variable. In addition, dependent variable is different in regression analysis where the coefficients $D$ functions as a categorical (Garson, 2009). In addition, unlike regression analysis, dependent variable is categorical in the discriminant analysis.

\section{Variables Used in the Analysis}

The independent variables of the research were chosen to be the following.

Under-five mortality rate (probability of dying by age five per 1,000 live births) $\left(x_{1}\right)$, number of physicians (per 1,000 population) $\left(x_{2}\right)$, health expenditure per capita (PP US\$) $\left(x_{3}\right)$, total expenditure on health as $\%$ of gross domestic product expenditure (\%) $\left(x_{4}\right)$, immunization coverage among one-years-olds with one dose of measles $(\%)\left(x_{5}\right)$, number of hospital beds per 1,000 people $\left(x_{6}\right)$, per capita recorded alcohol consumption (litres of pure alcohol) among adults $\left(x_{7}\right)$, fertility rate $(\%)\left(x_{8}\right)$, prevalence of current tobacco use among adults $(\geq 15$ years) (\%) $\left(x_{9}\right)$, life expectancy (year) $\left(x_{10}\right)$. These variables will be explained in further detail below.

Child mortality is one of the most crucial and avoidable global health concerns (Moser, Leon, \& Gwatkin, 2005, p. 1180). Under-five mortality rate estimates the number of new-born babies that will die before reaching their fifth birthday, based on current age-specific mortality rates for each country. "It provides a key baseline indication of how a country is progressing with its plan to realise children's rights, in particular their rights to life, health-care services, nutrition, water, social security and protection" (Children's Institute, 2006). Therefore, the mortality rate of under the age of five is adopted as an indicator for not only for health but also for development in general. This indicator was relied heavily as evidence of socio-economic development in the research conducted by Anderson Romani, Phillips, and Zyl (2002), Sen (1998), Chung and Muntaner (2006), and Moğultay (2005).

The total fertility rate (TFR) is a more direct measure of the level of fertility than the crude birth rate, since it refers to births per woman. This indicator shows the potential for population change in the country.

Tracking trends in fertility and birth rates helps support effective social planning and the allocation of basic resources across generations. Sustained high fertility rates create large populations of young dependents, creating demand for supports for young children, for an adequate number of schools, and for affordable child care. (Child Trend Databank, 2009)

Per capita recorded alcohol consumption (litres of pure alcohol) among adults is defined litres of pure 
alcohol per capita, computed as the sum of alcohol production and imports, less alcohol exports, divided by the adult population (aged 15 years and older). Harmful use of alcohol is related to many diseases and health conditions, including chronic diseases such as alcohol dependence, cancer, and liver cirrhosis, and acute health problems such as injuries. The prevalence of current tobacco smoking among adults is an important measure of the health and economic burden of tobacco, and provides a baseline for evaluating the effectiveness of tobacco control programs over time. While Junoy (1998) and Schieber, Poullier, and Greenwald (1994) analyze the alcohol and cigarette consumption, Gauld (2006) included the factor of cigarette consumption in his analysis of the remaining variables.

On one hand, while the United Nations or regional health achievements uses the life expectancy measure to show how each country offers equitable distributions of health services throughout a country, on the other hand it is also used as a social and economic indicator (DPT, 2006, p. 201), as it is recognized as an output of the countries' health management function (Kumar \& Özdamar, 2004, p. 83). Life expectancy, despite being a reflection of health, nutrition, sanitation, accessibility of clean water and income combined, can also reflect cost and unemployment (United Nations, 2005, p. 7).

The most important indicators mentioned in the Millennium Development Goals (MDGs) is proportion of one-years-olds children immunized against measles (Nath, Singh, Awasthi, Bhushan, Kumar, \& Singh, 2007). This rate is a sensitive indicator of the health of a population and the capacity of a health system to deliver essential services (Block, 1997, p. 196). These thoughts on the way, S. Mirmirani and T. Mirmirani (2005) included the children immunized against measles; Anderson and Hussey (2001) included those who had been immunized under the scheme of the health services in their respective studies.

Health financing is a critical component of health systems (World Health Organization, 2007). In this study, health expenditures per capita (PPP US\$) and total expenditure on health as percentage of gross domestic product (percentage of GDP) variables are used in the analysis. Research by Anand and Ravallion, as well as Bidani, Ravallion and Hojman on public health spending has shown a significant impact on the health status of the society (Gupta, Verhoeven, \& Tiongson, 1999). "The capita and the GDP are often used to measure a country's performance with respect to the level of investment or expenditure devoted to health care in comparison to other countries" (Klauvus \& Linna, 2004).

In the health sector, the number and quality of manpower serves as one of the most important conditions of employment. Health services and the specialized practitioners, dentists, pharmacists, nurses, midwives and other health care personnel to keep a significant role, even though physicians in the primary role (Özlü, 2008); consider the analysis, "1,000 people who fall into the number of physicians", wherein the number of physicians has also been taken as a significant variable.

Actual numbers of hospital beds per 1,000 people also constitutes one significant variable that contributes to an understanding of health services, and allows researchers to make effective comparisons about equality and development between countries (Denizli Valiliği, 2007).

\section{Results of Analysis}

In this study, the dependent variables constitute three groups (categories). As it is known, until 2004, the European community has developed through five enlargement processes. In the study, the countries don't become 
community members until the fourth expansion, and are defined as the former members of the country: (1) the countries become the community members at the fifth expansion and are called the member; (2) and in 2004 the countries which make ongoing negotiations to become members are classified as the candidate countries; and (3) for defining the groups, both founding members and the member countries until 2004 are called the former members, the countries became members in 2004 are called new members. The accuracy of the groups is determined by the MANOVA. It is accepted that the grouping has been made accurately, as it was found out that there are differences between the two groups $\left(\mathrm{H}_{0}\right.$ rejected). One of the main arguments of discriminant analysis is to ensure the covariance equality between groups. To test this assumption, Box's M Statistics is used (Tacq, 1999).

Five percent significance level, as seen in Table 1 and null hypothesis $\left(\mathrm{H}_{0}\right)$ is accepted. Covariance matrices do not differ between groups formed by the dependent. The right of the multivariate normality assumption is not a test commonly used in single variable analysis made by the normality (Tabachnick \& Fidell, 1996, p. 532).

The analysis results derived in the two functions, the first function for the eigenvalues $(0.889) 99.5 \%$ total variance to explain, $0.5 \%$ in the second explains (see Table 2 ).

Calculations for the two functions derived to test the relevance of the Wilk's Lambda eigenvalues (see Table 3) are taken into account in the sense that the first function is significant $(p=0.000)$ and the latter is not $(p=0.497)$.

Discriminant function coefficients are examined (see Table 4). Per capita health spending $\left(x_{3}\right)$ and the average life expectancy $\left(x_{10}\right)$ variable-members and former members of the candidate countries are effective in separate variables that can be seen in this study.

Table 1

Box's Test of Equality of Covariance Matrices

\begin{tabular}{lllll}
\hline Box's M & $F$ Approx & $d f 1$ & $d f 2$ & Sig. \\
\hline 10.911 & 1.344 & 6 & 234.519 & 0.238 \\
\hline
\end{tabular}

Table 2

Eigenvalues

\begin{tabular}{lllll}
\hline Function & Eigenvalue & \% of variance & Cumulative \% & Canonical correlation \\
\hline 1 & $3.756^{\mathrm{a}}$ & 99.5 & 99.5 & 0.889 \\
2 & $0.019^{\mathrm{a}}$ & 0.5 & 100.0 & 0.137 \\
\hline
\end{tabular}

Note. ${ }^{\text {a }}$ First 2 canonical discriminant functions were used in the analysis.

Table 3

Wilk's Lambda

\begin{tabular}{lllll}
\hline Test of function(s) & Wilks' Lambda & Chi-square & $d f$ & Sig. \\
\hline 1 through 2 & 0.206 & 38.668 & 4 & 0.000 \\
2 & 0.981 & 0.461 & 1 & 0.497 \\
\hline
\end{tabular}

Table 4

Standardized Canonical Discriminant Function Coefficients

\begin{tabular}{llc}
\hline & \multicolumn{2}{c}{ Function } \\
\cline { 2 - 3 } & 1 & 2 \\
\hline$x_{3}$ & 0.801 & -0.600 \\
$x_{10}$ & 0.560 & 0.830 \\
\hline
\end{tabular}


It is known spending per capita health in a certain country, when associated with health expenditure per capita, is considered as one of the basic health indicators by WHO. Having analysed countries included in health expenditure per capita calculations, Luxemburg, with $\$ 5,178.00$, is in the top position, whereas Bulgaria (\$671.00), Turkey (\$557.00) and Romania (\$433.00) take last three positions.

Another discrimination factor among countries is life expectancy. Life expectancy not only indicates the quality and equitable distribution of health services but also is accepted and broadly used as a social and developmental measure and as an outcome of countries health production functions (Kumar \& Özdamar, 2004, p. 83). Analysis of the countries including Italy and Sweden are the highest for life expectancy, while Turkey, Greece and Bulgaria with the lowest life expectancy in the back row are striking.

The structure matrix table below shows the correlations of each variable with each discriminant function (see Table 5), where $x_{3}$ variables contribute to the functionality of $0.829, x_{10}$ is the contribution made, and 0.60 is the capability.

Table 5

Structure Matrix

\begin{tabular}{llc}
\hline & \multicolumn{2}{c}{ Function } \\
\cline { 2 - 3 } & 1 & 2 \\
\hline$x_{3}$ & 0.829 & -0.559 \\
$x_{10}$ & 0.600 & 0.800 \\
\hline
\end{tabular}

Eighty five point seven percent of original grouped cases are correctly classified. Moreover, as a result of the analysis, Bulgaria, Turkey and Romania's membership were accurately observed in this study.

\section{Conclusion}

In this article, we tried to reveal the differences and similarities between Turkey and these new member countries in terms of health indicators, which could help Turkey, clear its unique hurdles to bring its health status in line with that of the EU.

The analysis determines the "available health expenditure per head" and the "life expectancy" for former EU members, current EU members and future EU members using general health indicators (from 2004). In addition to this, the comparison between Turkey and the two recent EU members Bulgaria and Romania from 2007 is regarded as an interesting issue, as the analysis reveals significant similarities with regards to general health.

Turkey's health status has not yet reached a satisfactory level, either absolutely or when compared to the EU members but it is not different from members whom joined recently, Bulgaria and Romania, and other such applicants. When comparisons of health expenditures are made across the EU countries, those which spend more money on health services have healthier populations than Turkey, which spends less (Kısa, Kavuncubaş1, \& Ersoy, 2002, p. 93). However, the question that should be answered first is: Is the Turkish Health Care System ready to be a part of the European Union (Kısa, Kavuncubaş1, \& Ersoy, 2002) or is the European Union ready to accept Turkey as a member like Bulgaria and Romania, which have nearly the same or worse health status?

With regards to future research, a number of different sectors may be included, and by doing so Turkey's position in comparison to new member states can be determined. The conclusions drawn from such research can judge the appropriateness of the length of time some future member states have to consider before being admitted 
to the EU. Similar analyses can be conducted by including further future member states in the research.

\section{References}

Anderson, B. A., Romani, J. H., Phillips H. E., \& Zyl, V. J. A. (2002). Environment, access to health care, and other factors affecting infant and child survival among the African and colored populations of South Africa, 1989-1994. Population and Environment, 23(4), 349-364.

Anderson, G., \& Hussey, P. S. (2001). Comparing health system performance in OECD Countries. Health Affairs, 20(3), $219-232$.

Ay, E. (2007). OECD raporlarında ülkemizin enleri. AR\&GE Bülten, İzmir Ticaret Odası. Retrieved from http://www.izto.org.tr/NR/rdonlyres/7475BDA1-95B7-4855-B351-9ADCE4362AFE/7897/OECDrapor_elif.pdf

Bal, H., \& Orkcu, H. H. (2005). Combining the discriminant analysis and the data envelopment analysis in view of multiple criteria decision making: a new model. G. U. Fen Bilimleri Dergisi, 18(3), 355-364.

Block, M. A. G. (1997). Comparative research and analysis methods for shared learning from health system reforms. Health Policy, 42(3), 187-209.

Children's Institute. (2006). Under five mortality rate. Retrieved July 01 , 2009 from http://www.childrencount.ci.org.za/uploads/brief_child-deaths.pdf

Chung, H., \& Muntaner, C. (2006). Political and welfare state determinants of infant and child health indicators: An analysis of wealthy countries. Social Science and Medicine, 63, 829-842.

Denizli Valiliği. (2007). Öncelikli yaşam kalitesi göstergeleri. Retrieved November 23, 2007, from http://www.denizli.gov.tr/valilik/oncelikliyasam/gosterge.doc

DPT. (2006). Ekonomik ve sosyal sektörlerdeki gelişmeler. VIII. Beş Yıllık Kalkınma Planı (2001-2005) 2005 Yı1ı Programı Destek Çalışmaları. Retrieved June 1, 2009 from http://ekutup.dpt.gov.tr/program/2004/destek04.pdf

Garson, D. (2009). Discriminant function analysis. Retrieved July $7, \quad 2009$ from http://faculty.chass.ncsu.edu/garson/PA765/discrim.htm

Gauld, R., Ikegami, N., Barr, M. D., Chiang, T. L., Gould, D., \& Kwon, S. (2006). Advanced Asia's health systems in comparison. Health Policy, 79(3), 325-336.

Gupta, S., Verhoeven, M., \& Tiongson, E. (1999). Does higher government spending buy better results in education and health care. IMF working paper, WP/99/21.

Hair, J., Anderson, R., Tatham, R., \& Black, W. (1998). Multivariate data analysis (5th ed.). New Jersey: Prentice Hall.

Junoy, J. P. (1998). Measuring health production performance in the OECD. Applied Economic Letters, 5(4), 255-259.

Kısa, A., Kavuncubaş1, S., \& Ersoy, K. (2002). Is the Turkish health care system ready to be a part of the European Union? Journal of Medical Systems, 26(2), 89-95.

Kisa, A., Younis, M. Z., \& Kisa S. (2007). A comparative analysis of the European Union's and Turkey's health status: How health-care services might affect Turkey's accession to the EU. Public Health Rep, 122(5), 693-701.

Klauvus, J., \& Linna, M. (2004). International comparisons of health expenditure: A serious policy-tool? Global Forum for Health Research Forum, Mexico City.

Kumar, A., \& Özdamar, L. (2004). International comparison of health care systems. International Journal of the Computer, The Internet and Management, 12(3), 81-95.

Mirmirani, S., \& Mirmirani, T. (2005). Health care delivery in OECD countries, 1990-2000: An efficiency assessment. The Business Review, 3(2), 58-63.

Moğultay, S. (2005). Çocuk să̆ll̆̆g ve hastalıkları kliniğinde 2004 yılı içinde yatan hastaların retrospektif olarak taranması (Doctoral Dissertation Haydarpaşa Numune Eğitim ve Araştırma Hastanesi, İstanbul).

Moser, K. A., Leon, A. A., \& Gwatkin, D. R. (2005). How does progress towards the child mortality millennium development goal affect inequalities between the poorest and least poor? Analysis of demographic and health survey data. BMJ, 331 (7526), $1180-1182$.

Nath, B., Singh, J. V., Awasthi, S., Bhushan, V., Kumar, V., \& Singh, S. K. (2007). A study on determinants of immunization coverage among 12-23 months old children in urban slums of Lucknow district. India, Indian Journal of Medical Sciences, 61(11), 598-606.

Özlü, T. (2008). Hekim sayıs1 az m1 cok mu? Medimagazin, 397. Retrieved January 28, 2010, from http://www.medimagazin.com.tr/authors/tevfik-ozlu/tr-hekim-sayisi-az-mi-cok-mu-72-45-1710.html 
Pacifico, I. R. S. (2004). Welfare in the mediterranean countries Republic of Turkey. Retrieved February 10, 2010, from http://unpan1.un.org/intradoc/groups/public/documents/CAIMED/UNPAN018932.pdf

Schieber, G., Poullier, J. J. P., \& Greenwald, L. M. (1994). Health system performance in OECD Countries: 1980-1992. Health Affairs, 13(4), 100-112.

Sen, A. (1998). Mortality as an indicator of economic success and failure. The Economic Journal, 108(446), 1-25.

Tabachnick, B., \& Fidell, L. (1996). Using multivariate statistics (3rd. ed.). USA: Harper Collins.

Tacq, J. (1999). Multivariate technique in social sciences. Great Britain: Sage Publications.

Vehid, S. (2000). Temel demografik ve sağlık düzeyi ölçütleri açısından Türkiye ile Avrupa Birligi’ne (AB) üye ülkelerin karşılaştırılması. Cerrahpasa Tip Dergisi, 31(2), 100-106.

World Health Statistics. (2007). Retrieved January $16, \quad 2008$, from http://www.who.int/whosis/indicators/compendium/2008/2ptu/en/index.html

Yıldırım, H. H. (2004). Avrupa Birliği sağlık politikaları ve Avrupa Birliği'ne üye ve aday ülke sağllk sistemlerinin karşılaştırılması teknik verimlilik analizi (Doctoral Dissertation, Hacettepe Üniversitesi Sağlık Bilimleri Enstitüsü Sağlık Kurumları Yönetimi, Ankara). 